\title{
Does Multiculturalism Inhibit Intercultural Dialogue? Evidence from the Antipodes
}

https://doi.org/10.1515/jcgs-2018-0002

\begin{abstract}
In recent years, an international debate has erupted over whether and how interculturalism differs from multiculturalism as a response to cultural diversity. An influential argument in this debate is that multiculturalism itself militates against intercultural dialogue. This article scrutinises this argument and challenge its applicability in the Australian context. I examine two case studies of fraught intercultural dialogue: the 2006 clash between the Howard government and the Ethnic Communities' Council of Victoria over the proposed introduction of a citizenship test; and the Abbott government's proposed reform of the anti-vilification provisions of the Racial Discrimination Act 1975 (Cth) during 2013-14. The cases suggest that far from undermining intercultural dialogue, respecting the terms of Australian multiculturalism would help to make it possible. Moreover, the cases suggest that if pursued genuinely, intercultural dialogue could contribute improved policy outcomes.
\end{abstract}

Keywords: multiculturalism; intercultural dialogue; Australia; citizenship test; free speech; racial hatred provisions.

In recent years, a lively debate has erupted over whether and how interculturalism differs from multiculturalism as a response to cultural diversity (for example, Meer, Modood, \& Zapata-Barrero 2016; Barrett 2013; Meer \& Modood 2012; Kymlicka 2012; Levey 2012; Taylor 2012; Wieviorka 2012; Bouchard 2011). An influential argument in this debate is that multiculturalism itself militates against intercultural dialogue (ICD) (for example, Zapata-Barrero 2015; Cantle 2012; Council of Europe 2008). In this article, I want to scrutinise this argument and challenge its applicability in the Australian context.

Australia helped to pioneer multicultural policy along with Canada in the1970s and 1980s, a policy it has maintained. ${ }^{2}$ Superficially, the Australian case might seem to support the contention that multiculturalist regimes inhibit ICD, as the latter has scarcely figured in the Australian national experience. Even the term "intercultural dialogue" has little resonance in public affairs. The government consults a wide range of stakeholders, including minorities, when fashioning policy. However, there is little inclination or appetite for a serious, sustained and genuinely open engagement with cultural minorities on issues that directly

1 This article is a revised version of Geoffrey Brahm Levey (2017) 'Intercultural dialogue under a multiculturalism regime: pitfalls and possibilities in Australia' in Fethi Mansouri (ed) Interculturalism at the crossroads: comparative perspectives on concepts, policies and practice, United Nations Educational, Scientific and Cultural Organization, France, pp. 103-25.

2 At least until March 2017 when the Turnbull government launched a new national multicultural policy statement (DSS 2017). The new policy stresses the importance of inclusion and a sense of belonging for all Australians. However, unlike the previous national multicultural policy statements, the Turnbull policy places most of the onus on immigrants and minorities to adjust to Australian life. It scarcely addresses the measures that government and public institutions will take to be more accommodating of cultural diversity and the needs of minorities. In another first, the new multicultural policy avoids using the word "multiculturalism".

\footnotetext{
*Corresponding author: Geoffrey Brahm Levey, UNSW Sydney, Kensington, NSW, Australia E-mail: g.levey@unsw.edu.au
} 
affect them and their place in the Australian society, notwithstanding the almost 40-year commitment to state multiculturalism.

I argue that the paucity of ICD in Australia at the governmental level can be traced to the indifferent attitude of "Anglo-Australia" towards minorities. My contention is that ICD would be both possible and positive for policy outcomes if the terms of Australian multiculturalism were actually respected. To support these arguments, I analyse two prominent cases in recent political history. The first is the 2006 clash between John Howard's conservative government and the Ethnic Communities' Council of Victoria (ECCV) over the introduction of a citizenship test. The second case concerns the attempt by Tony Abbott's conservative government during 2013-14 to reform the anti-vilification provisions of the Racial Discrimination Act 1975 (Cth). The cases highlight how Australia's multiculturalism regime is circumvented in avoiding ICD.

\section{Why the Paucity of ICD in Australia?}

Two very different arguments have been put as to why multiculturalism works against ICD. According to one account, multiculturalism as a public philosophy and policy has this effect because it treats cultural minorities as discrete communities mainly interested in their own identity preservation. Although such an approach may have made sense in the post-war decades when cultural communities were concerned with resisting the pressures of assimilation, these conditions, so goes the argument, no longer apply. In today's globalised world, which includes mass travel and instantaneous communications, what is needed instead is a model that allows for cosmopolitan interests and attachments, where cultural-group members, who are open and forward-looking rather than culturally blinkered by their pasts, can interact, exchange and dialogue with diverse others. In a word, what is needed is "interculturalism" rather than multiculturalism (Cantle 2012; Zapata-Barrero 2015).

This interculturalist critique of multiculturalism is unconvincing. For one thing, it overlooks versions of multiculturalism that stress ICD (for example, Parekh 1996, 2000). However, it also misses the mark regarding the Australian experience. Even in its early years, when the tendency was to construe ethnic minorities as discrete communities, Australia's multicultural policy did not preclude interaction between cultural minorities. To take one example, the Ethnic Communities' Councils of Australia in each state of Australia was among the first non-government institutions established to advance the multicultural agenda in Australia. The Councils comprised representatives of all ethnic groups that wished to participate. Nor has Australian multiculturalism boxed people into their ethnic, religious or linguistic group heritage. Australian multicultural policy has always been highly individualistic. The rights to cultural identity and respect and to access and equity apply to individual Australians, however, they define and practice (or not) their cultural identities. As the National Agenda for a Multicultural Australia puts it, "Fundamentally, multiculturalism is about the rights of the individual" (OMA 1989, p. 15). Individuals are free to identify themselves with their cultural heritage groups, assimilate into the mainstream or forge hybrid identities and patterns of identification. Interaction and dialogue with diverse others is a standard operating procedure among individual Australians.

A second line of criticism is that multiculturalism is based on an unhelpful majority/minority dichotomy. The Council of Europe's (2008, p. 18) White Paper on Intercultural Dialogue contends that although multiculturalism "was ostensibly a radical departure from assimilationism", it "in fact ... frequently shared the same, schematic conception of society set in opposition of majority and minority, differing only in endorsing separation of the minority from the majority rather than assimilation to it”. This observation takes us a step closer to the heart of the matter. Australian multiculturalism is formulated on the basis of a dominant cultural majority - typically, dubbed Anglo-Australians or Anglo-Celts - and the rest, a plethora of minorities. All five national multicultural policy statements reference the foundational institutions and culture based on British heritage and and/or European settlement, Torres Strait Islanders and their distinct experience as the original and dispossessed inhabitants and the large and growing proportion of the population who are immigrants or the children of immigrants, many from non-Englishspeaking backgrounds (OMA 1989; Commonwealth of Australia 1999, 2003; DIAC 2011; DSS 2017). 
Neither multiculturalism nor Australia's particular version of it is, however, the problem in this respect. First, not every iteration of multiculturalism is based on a majority/minority dichotomy. Much multicultural theory argues for broad parity or even-handedness in state recognition and accommodation across all constituent groups in a society (for example, Bader 2007; Carens 2000; Fraser 2002; Young 1990). Bouchard (2011, p. 463) notes that federal Canada's policy of multiculturalism officially operates on a "diversity" paradigm that does not recognise a majority culture and instead places all constituent groups and individuals on an equal footing. Rather, he says, it is Quebec's interculturalism policy that endorses a "duality" paradigm that sanctions a foundational majority culture and "ad hoc majority precedence" (Bouchard 2011). The Canadian case, in other words, exhibits the very opposite terminological situation to that asserted by the Council of Europe. It is clear that the labels "multiculturalism" and "interculturalism" have highly variable and contextual meanings (Levey 2012, 2016; Meer \& Modood 2012). Treating these labels as though they represent fixed and contrasting approaches to cultural diversity is bound to be misleading.

Second, Australian multiculturalism has always sought to sensitise "Anglo-Australia" to the necessity of understanding and being responsive to Australia's minorities. For example, an early policy discussion paper, "Multiculturalism for All Australians: Our Developing Nationhood", observed that if Australia's core institutions are to be relevant to all Australians, then "they will sometimes have to go out of their way to understand the diverse cultural backgrounds of the many groups comprising Australian society" (ACPEA 1982, p. 16). The architects of Australian multiculturalism understood that intercultural exchange is essential for building inclusive relations because, without it, one is unlikely to appreciate what is even at issue or how one may be undermining positive relations, despite one's best intentions.

Bouchard's suggestion of looking beyond the labels to the underlying paradigms at work is more pertinent. Some multiculturalism and some interculturalism operate on a duality paradigm involving an established majority and culture and then the rest of the population. However, even this paradigmatic level only takes us so far in explaining national differences. If both Quebec's and Australia's cultural diversity policies are predicated on a majority/minority duality, why is it that Quebec has proved comparatively open to and adept at ICD, whereas Australia has not?

The paucity of ICD in Australia's dealings with its minorities is not attributable to its multicultural policy. Nor can it be explained simply in terms of there being an underlying majority/minority duality governing Australia's approach to cultural diversity. Rather, the paucity of ICD is a corollary of how the dominant cultural majority goes about exercising its dominance. This is an attitudinal matter with deep historical, cultural and institutional underpinnings. Australian multiculturalism was intended to combat and civilise these longstanding attitudes and practices. That they still prevail is testimony not to the effect of multicultural policy but to its limitations in the face of entrenched cultural patterns and political interests.

There is no shortage of examples. Multicultural policy proclaims, and Australian governments stress, the importance of all Australians respecting the country's democratic traditions and institutions. John Howard's conservative government was telling Muslims in 2005 that they must abide by democratic norms, and yet, at the same time, it was also telling the Muslim and indigenous communities who among their number would represent them in their dealings with government (DIMA 2006; Kuhn 2009; Shaw 2004). Not exactly a lesson in democratic representation, let alone an ICD. In 2008, Kevin Rudd's Labor government convened a national summit designed to bring together 2000 of Australia's best and brightest individuals to discuss future directions for the nation. This plan did not stop the Prime Minister from scheduling the summit on the first days of the festival of Passover, thus ensuring that many of the Jewish Australians invited could not participate in the discussions (Australian Jewish News 2008). It is almost as if multicultural policy did not exist.

Let us consider two cases in some detail. The first is the 2006 clash between the Howard government and the ECCV over the proposed introduction of a citizenship test. The second case concerns the failed attempt by the Abbott Coalition government in 2013-14 to reform the anti-vilification provisions of the Racial Discrimination Act 1975 (Cth). The first case reveals how a pretence of dialogue quickly deteriorates into a pointless spat when there is little trust in the government's bona fides and when parties to the 
dialogue resort to loose language and fail to respect the ground rules of Australian multiculturalism. The second case reveals a government wholly uninterested in seriously dialoguing about a major reform that is overwhelmingly opposed by minorities and the public at large and which results in the government's humiliating defeat. The cases are instructive in identifying not only the difficulties but also the importance of conducting ICD in Australia.

\section{Case Study 1: The Howard government's stoush with the ECCV}

The background to the case is as follows. On 17 September 2006, the Parliamentary Secretary for Multicultural Affairs and Citizenship, Andrew Robb, released a discussion paper, "Australian Citizenship: Much More Than a Ceremony", to seek the Australian community's views on the merits of introducing a formal citizenship test (Commonwealth of Australia 2006). The paper sought comment on a range of questions having to do with the need for, and nature of, such a test, including facility in English language and familiarity with Australia's values and way of life. On the face of it, this seemed a promising initial step towards the public and ICD.

The ECCV (2006a) submitted its responses to these questions on 15 November 2006. It argued that the case for change had not been made; that the proposed reforms were discriminatory, especially in relation to refugees from Africa; and that the government's stress on "Australian values" was bogus. In an address to a conference later that month, Parliamentary Secretary Robb took exception to the ECCV's position, characterising it as "essentially a separatist view" (Robb 2006a). The ECCV (2006b) issued a media release the same day rejecting this characterisation and contending that Robb had misunderstood their position. Two days later, the ECCV's Executive Officer Peter van Vliet (2006) rounded on the Howard government and its proposed citizenship test in an opinion piece in a Melbourne newspaper. The "dialogue" between the ECCV and the government, such as it was, never recovered from this point.

The episode is salutary because both parties diminished public debate and undermined ICD by conflating positions and engaging in unwarranted provocations. Moreover, both the government's and the ECCV's positions failed to respect the terms of Australian multiculturalism. Before I defend these contentions, some broader context is required.

First, Prime Minister Howard was well known as an arch opponent of multiculturalism. After assuming power in 1996, for several years, Howard could not bring himself even to say the word multiculturalism (Kelly 1997). Although the Howard government nominally continued multicultural policy, a number of institutions (such as the Bureau of Immigration, Multicultural and Population Research) were abolished and funding was reduced. The 2003 policy statement, Multicultural Australia: United in Diversity, was a mere five pages long and suggested a government going through the motions (Commonwealth of Australia 2003). There was a palpable sense that it was only a matter of time before the Howard government would recant on multiculturalism.

That time came in late 2006 in the wake, secondly, of international developments. Following a spate of Islamist terror attacks abroad and reassessments of multiculturalism and general concerns about the integration of especially Muslims in Britain and the Netherlands, the Howard government signalled its intention to drop the word "multiculturalism" from government use (Robb 2006a). In January 2007, for example, the Department of Immigration and Multicultural Affairs was renamed the Department of Immigration and Citizenship. In addition, the residency eligibility period for acquiring citizenship was extended from two to four years.

The government's proposed citizenship test was thus widely perceived as being part of Howard's move against multiculturalism. In this light, the government's discussion paper exploring a citizenship test takes on a different hue. Was the government genuinely seeking to consult the public and stakeholders on the idea? Or was the discussion paper rather a public relations exercise to "sell" a reform that had already been finalised and to which it was already committed? The paper itself observes the best bureaucratic protocols of the genre: the language is inquisitive, searching and tentative. It concludes with a useful survey of citizenship tests and procedures that other comparator countries have adopted. 
Barely a month after the release of the discussion paper, however, the Parliamentary Secretary gave a different impression. In an address to the Jewish National Fund in Melbourne, Robb responded to common criticisms of the proposal and otherwise made the case for the new test (Robb 2006b). This was expected. Robb even advanced the debate, I think, by effectively rebutting a few criticisms of the proposal. To the argument "if it ain't broke, don't fix it", Robb replied that the "system is not 'broke' because we have continually sought to improve it". To the complaint that many migrants to Australia have become good citizens with little fluency in English, Robb noted how that incontrovertible fact is connected to labour conditions in the 1950s and 1960s, when migrants mainly filled unskilled and labour-intensive industries. The Australia of today, he retorted, is a service-based economy that requires English facility to secure employment and advance (Robb 2006b).

The problem lay with Robb's concluding remarks. Early in his address, he was careful to stress that the "proposed formal citizenship test ... is the subject of a discussion paper and public consultations at the present time". However, the concluding section states the benefits of a citizenship test in such unequivocal terms that it presents the option of not proceeding with the proposal as morally and politically irresponsible. Robb left little doubt that the government was committed to a citizenship test and had decided its format ahead of the public consultations.

The ECCV entered the public debate a few weeks later on 15 November 2006 (ECCV 2006a). Its main concern, it said, was that the proposed citizenship test would unfairly burden migrants from non-Englishspeaking backgrounds and, especially, refugees from Africa. The concern was a reasonable one. Early data suggested that the failure rate of the test within its first year was higher than 20 per cent, with refugees and people from non-English-speaking backgrounds faring even worse (Butterly 2008). Although rates soon improved to less than 4 per cent failing overall on the first attempt, there remained considerable variation based on national origin (Anderson 2015). Most of the ECCV's fire was directed, however, at the government's account of Australian values. The discussion paper lists these values as including respect for the freedom and dignity of the individual, support for democracy, commitment to the rule of law, equality of men and women, the spirit of a fair go and mutual respect, and compassion to those in need (Commonwealth of Australia 2006, p. 11). The ECCV understood this list as suggesting that the underlying premise of the discussion paper is that Australia is a monocultural society with "one overriding culture", a phrase that Robb invoked in his foreword to the paper. The ECCV said that they endorsed only democracy, the rule of law and Australia as "our shared homeland". They would not ascribe Australian value status to respect for the individual, equality and a fair go and mutual respect (ECCV 2006a).

The ECCV's reservations about some of the claimed core Australian values are hard to fathom. The core Australian values listed in the discussion paper are almost identical to the core values and institutions specified in Australia's successive multicultural policies, namely, reciprocity, tolerance and equality (including of the sexes), freedom of speech and religion, the rule of law, the Constitution, parliamentary democracy and English as the national language (Commonwealth of Australia 1999, 2003; DIAC 2011; OMA 1989). Yet the ECCV had never before objected to this list of values and now claimed to be upholding Australian multiculturalism against a perceived attack by the government. The ECCV bracketed "respect for the individual" because it "draws on Western liberal traditions". They said that such a value is problematic because the discussion paper ignores "social democratic or communitarian values which are also part of Western liberal and democratic traditions" (ECCV 2006a). It is unclear why a fair go, equality, mutual respect and compassion for the needy do not count as social democratic values. It is also unclear how rejecting this subset of the listed core values can be reconciled with the ECCV's concern about discrimination and the plight of refugees.

The ECCV objects to a fair go and mutual respect on the grounds that they are "hardly Australian values", being rather "universal values found in a vast array of nations and among different religious and secular belief systems". This observation scarcely explains why these values can or should not also be Australian values; the ECCV's favoured Australian values of democracy and the rule of law are also practiced by many other nations.

Seeking to engage in a public dialogue over the proposed citizenship test is commendable. However, the ECCV's curious stance on Australian values allowed the government to avoid confronting its own 
contortions regarding Australian multiculturalism. The Parliamentary Secretary quickly accused the ECCV of "separatism": "When a group as prominent as the Ethnic Communities Council of Victoria rejects, in the name of multiculturalism, the notion of an overriding Australian culture based around a core set of values we have a problem because this is essentially a separatist view" (Robb 2006a). In fact, for all its incoherence, the ECCV's position strains the meaning of separatism. They were not arguing for secession or self-government; they were endorsing the same democratic system and the same law for the same country. Indeed, it is hard to imagine how a body like the ECCV could be separatist, a point made by the ECCV (2006b) in its reply to Robb. The organisation is law abiding and participates in the social, cultural and political life of Australia. It represents dozens of community groups, themselves representing hundreds of thousands of Australian individuals who are also immersed in, and committed to, the life and institutions of the country as it is presently constituted.

The charge of separatism was not the only instance of loose language used by the Parliamentary Secretary. In his address to the 2006 Transformations Conference at the Australian National University, Robb (2006a) had much to say about community, core values, citizenship, Australian national identity and Australian culture. Unfortunately, much of what he had to say collapsed these notions into each other, as if they all amounted to the same thing. They do not.

At the heart of Robb's position is a legitimate concern of any democratic state, namely, national and social integration. He worried that the term multiculturalism has been misinterpreted or misappropriated by some groups as sanctioning "separate development, a federation of ethnic cultures, not one community". One might argue that this worry is misplaced in the Australian case. Although it may have a basis in Britain, the Netherlands and perhaps some other places, Australia has a far more selective immigration program (Hartwich 2011), as Robb himself acknowledged. Moreover, ever since the inception of multiculturalism, Australian governments have recognised that many Australians do not much understand it. Previously, their response had been a renewed commitment to better explain and promote the policy. People rightly wondered why some misunderstanding of multiculturalism in the community should suddenly require the word, if not the policy, to be dumped.

However, here I want to put aside these points to simply grant the in-principle interest of democratic states in political and social integration. My concern is how this valid point gets lost amid careless language and allusions. For example, Robb's legitimate objection to "separate development" and a "federation of ethnic cultures" becomes elsewhere in his address an objection to the emergence of a "community of communities" in Australia. Yet, Australia has been a community of communities for a very long time. How could it be not given the ethnic, linguistic, national and religious diversity of the country's inhabitants? One only needs to review the list of organisations that responded to the discussion paper, a veritable cross-section of Australia's multicultural society. Australia is certainly not a federation of ethnic cultures (although Victorians like to argue that New South Welshmen are culturally challenged). Nor is Australia only a community of communities; it is also a national community comprising individual citizens with multiple and varied interests and memberships. However, self-evidently Australia is also a community of a vast array of communities.

Denying this much unhelpfully raises the stakes of what Australia might otherwise be. Soon after the denial, the Parliamentary Secretary told his audience that "Australia has successfully combined people into one family with one overriding culture, based on a common set of values" (Robb 2006a). The ECCV was exercised by this reference to an "overriding culture", which, as noted, figured also in Robb's foreword to the discussion paper and which the ECCV equated with a "monocultural" society. To me, the word "overriding" implies the legitimate existence of other cultures. What is troubling is describing Australians as "one family". This is loose language commissioned to do political work. It implies a kind of relationship and degree of integration that is inappropriate for a liberal democratic political community. If Australians are one family, what are they doing marrying each other? The Howard government was concerned that all Australians should be proficient in English. All of us should be concerned how the government and others use and abuse the English language in these debates. Australia is not a federation of ethnic cultures, nor should it be. It is not one family, nor could it be. It is a community of communities; how could it not be? Finally, it is also something more than a community of communities: it is a national community of individual citizens. 
What, then, of Robb's "overriding culture" and "shared national identity"? Invoking "culture", let alone an overriding one, in the context of a citizenship test is bound to provoke stakeholders in a multicultural polity. However, one should not get too precious about such a term. Liberal democratic institutions and values can also be construed as constituting a certain culture. If by an "overriding culture" Robb meant the core Australian values as specified in multicultural policy - which is how he elaborated the phrase in his foreword to the discussion paper - he was not saying anything new or particularly controversial in the Australian context. The trouble is that the discussion paper proper seemed to enlarge the idea of core values.

The slide from a core set of values based on liberal democratic norms and institutions (as stipulated in multicultural policy) to Anglo-Australian cultural patterns and way of life is almost imperceptible if one is not alert to the significance of the distinction. The discussion paper identifies "themes on which applicants are tested in other countries", including "customs and traditions" (Commonwealth of Australia 2006, p. 12). It neglects to clarify that for Australia's main comparator nations - Britain, Canada and the United States - the customs and traditions tested are typically civic in nature, such as public holidays, historical commemorations and national symbols, or, in Britain's case, also practical information for "getting by" (A previous British citizenship test asked a multiple-choice question about what one should do if one accidently knocks over a patron's beer in a pub.). The discussion paper then asks whether prospective Australian citizens should have to demonstrate some knowledge of "Australian culture and traditions" as distinct from Australian history, national symbols and system of democracy (Commonwealth of Australia 2006, p. 13).

In his subsequent public addresses, Robb reinforced this impression of an expanded notion of culture by variously invoking "the Australian culture" and "Australia's way of life" (Robb 2006b) and equating an overriding culture and core values with the idea of a "shared national identity" (Robb 2006a). National identities surely exist and are important, but, as I have written elsewhere, the point about national identities is that they are dynamic and develop organically. They cannot be legislated, for the most part, without trading in gross caricatures and violating liberal democratic norms (Levey 2008). Least of all can a national identity be instilled in people through a general knowledge test.

For almost half a century, Australia followed the example of other liberal democracies and progressively redefined Australian citizenship from one of a national cultural community and emotional connection to it to one of "proceduralism" and the formal acceptance of rights and obligations (Betts 2002; Betts \& Birrell 2007). In 1986, for example, the requirement in the Australian Oath of Allegiance to state one's name and to renounce all other allegiances was dropped. In 1994, the Oath of Allegiance was replaced in its entirety with a Pledge of Commitment as a Citizen, in which reference to the Queen was omitted. The Australian Citizenship Amendment Act 2002 (Cth) permitted Australian citizens to acquire other nationalities without losing their Australian citizenship and so on. Yet here was the Howard government, in 2006, apparently seeking to renationalise citizenship. Indeed the citizenship test that Howard introduced controversially included questions on cricket heroes and other Anglo-Australian sporting and cultural icons along with questions on Australian political history and institutions (Levey 2014; Tate 2009).

The episode underscores a number of points. First, the Howard government's discussion paper on the citizenship test was less than a genuine attempt at public consultation and dialogue with interested parties on this significant reform. The government had clearly already decided on the test and its general format. Second, the ECCV was presented a prime opportunity to press the government on departing from its proclaimed core set of Australian values in the discussion paper (and in multicultural policy). However, the ECCV could not prosecute this case because of its own puzzling and indulgent rejection of this longsettled list of liberal democratic (and Australian multiculturalism) ground rules. Where the Howard government radically expanded the list to include cultural aspects associated with Anglo-Australian icons and norms, the ECCV radically eviscerated the list of core Australian values from seven to a skeletal three and thereby blew wind into the government's sails. Finally, Australian multiculturalism was not the cause but a victim of this failed attempt at public and ICD.

The Howard government was removed from office less than a year after the introduction of the citizenship test. Following a formal review, the Rudd Labor government removed the "cultural questions" 
from the Australian citizenship test, a situation that prevails to this day, notwithstanding two subsequent conservative governments. The Howard government's unfortunate and costly approach to citizenship reform was entirely avoidable. Had the government been genuinely interested in consulting the public and community groups and had the government and some influential ethnic advocacy groups respected the liberal democratic terms of Australian multiculturalism, a constructive dialogue about the merits and format of a new citizenship test would have been possible.

\section{Case Study 2: Abbott Government's Reform of the Racial Hatred Provisions}

Our second case study concerns an issue that underwrites the very possibility of public and ICD, namely, free speech and its appropriate limits. Freedom of speech is a fundamental right that entitles people to express their views and concerns. At the same time, hate speech can intimidate and marginalise individuals and groups such that they are or feel themselves to be excluded from the society. Since 1995, Australia has balanced these twin concerns with Part 2A of the Racial Discrimination Act 1975 (Cth) (RDA). Part 2A of the RDA addresses discriminatory action based on racial hatred. It also includes section $18 \mathrm{C}$, which renders unlawful behaviour that "offends, insults, humiliates or intimidates" in a discriminatory manner on the basis of a specified group characteristic. It also includes the 18D "exemptions" that protect action that is done reasonably and in good faith in artistic, scientific, academic or journalistic pursuits in the public interest. For some 16 years, these provisions served Australians well and without incident.

The latter changed in 2011. A federal court found conservative columnist Andrew Bolt to have breached the race hate laws in two published articles in which he had questioned the identity and motives of light-skinned indigenous people (Eatock $v$ Bolt 2011). Abbott, then Liberal party opposition leader and a friend of Bolt, denounced the decision and pledged to reform the RDA if elected to govern. Following the Abbott Coalition victory in September 2013, the Attorney General Senator George Brandis announced the government's intention to repeal the RDA's anti-vilification provisions in the name of free speech. Brandis stated that he wanted to "re-centre [the] debate so that when people talk about rights, they talk about the great liberal democratic rights of freedom of expression, freedom of association, freedom of worship and freedom of the press" (Wright 2013).

The proposed changes to the RDA sparked a public outcry, not least among cultural minorities. Their sense of acceptance and belonging in multicultural Australia is still largely tied to the legal protections against discrimination. The anti-vilification provisions of the RDA are considered to be a vital extension of the principle of nondiscrimination and a public sign of minorities' social acceptance. As reforming Labor Prime Minster Gough Whitlam (1975) proclaimed on its passing into law, "The Racial Discrimination Act wrote it firmly into the legislation that Australia is in reality a multicultural nation, in which the linguistic and cultural heritage of the Aboriginal people and of peoples from all parts of the world can find an honoured place". For cultural minorities, at stake was the message that a dilution of the federal protections would send about their standing in modern Australia; it would throw into question whether they still retained "an honoured place".

Brandis responded to the controversy by appointing an outspoken free-market libertarian, Tim Wilson, to the role of Human Rights Commissioner at the Australian Human Rights Commission in December 2013. Wilson had once called for the abolition of the Commission as an illegitimate use of state authority. Dubbed the "freedom commissioner" by Brandis, his role now was to balance the alleged social justice focus of the other commissioners and to prosecute the case for free speech as the most fundamental and cherished of all liberties. Wilson assumed the role with zeal, denouncing the protections against non-discrimination and of equal opportunity as dangerous "positive liberties" and further antagonising community groups.

The government's apparent deafness to public and minority group opposition to the proposed reform ironically saw leaders from the Greek, Arabic, Chinese, Indigenous, Jewish and other communities cooperating and mobilising against the changes like never before. In March 2014, the government 
circulated a draft of its proposed changes to the RDA for comment and announced that it would hold a review on the matter. The exposure draft proposed repealing sections $18 \mathrm{C}$ and $18 \mathrm{D}$ and replacing them with protections against vilification and intimidation on the basis of the race, colour or ethnic or national origins of a person or group of persons. However, the meaning of vilification was to be limited to the "incitement of hatred" and the meaning of intimidation was confined to causing "fear of physical harm" only. Furthermore, whether an act has these effects was to be determined "by the standards of an ordinary reasonable member of the Australian community, not by the standards of any particular group within the Australian community" (Brandis 2014). Not only was the government indifferent to minorities' concerns about watering down the anti-vilification provisions, now it was proposing to have people who likely had never known the hurt of racism decide what racial discrimination is and when it has occurred and to specifically exclude from the exercise those who know it best, namely, its routine victims. ICD and minority input could hardly have been further sidelined.

In August 2014, it was revealed that more than 76 per cent of the 4100 submissions to the review inquiry opposed the government's draft amendments (Aston 2014a). Days later, the Prime Minister announced that his government would no longer pursue changes to the RDA, saying "Leadership is about preserving national unity on the essentials and that is why I have taken this position" (Aston 2014b).

For some advocates of the government's proposed reform, such as the Attorney General, the issue was a matter of principle. Free speech, in their view, is simply too fundamental to liberty and democracy to be balanced against protection from discriminatory action of any kind. However, other advocates of the reform were primarily concerned about the insidious consequences of regulating speech. For them, such a regulation makes people overcautious about speaking their mind, introducing a "chilling" effect that drains public discourse of authenticity, which in turn undermines democratic legitimacy. This concern is the mirror image of the concern that certain kinds of speech can intimidate minority members from participating in the society as equals. In either case, is not a full and frank ICD made impossible?

This important issue was lost in the public debate. Those opposed to amending the RDA provisions sometimes challenged the reformers by asking, “What is it that you want to say that isn't already protected under section 18D?" (Soutphommasane 2014). It is a fair question, but it does not tackle the issue of the chilling effect. Sensing this, Commissioner Wilson (2015) rather unkindly called the question a "party trick". "The question assumes that one wants to say something racist, but that is not so", he protested. As an example, Wilson cited his own self-censorship on hearing the boxer Anthony Mundine say that Aboriginality and homosexuality are incompatible according to Aboriginal law. Wilson said that he wanted to "harshly criticise" the basis of Mundine's comment but because of section 18C, he and other nonAboriginal Australians "have to cautiously discuss the topic" lest they offend Mundine's "ethnic origins".

In fact, Wilson's example only highlights the force of the question he derides. What does he mean by criticising harshly? As Justice Bromberg made clear in his decision in Eatock $v$ Bolt (2011), section 18C does not prohibit anyone from critically discussing aspects of Aboriginal identity and tradition. Were Wilson's "harsh" criticism to be reasonably made - for example, by suggesting that if Aboriginal law condemns homosexuality, it is homophobic and discriminatory in just the way that Christianity, Judaism and Islam traditionally are - there would be no issue even if the remark upsets some Indigenous Australians. Were his "harsh" criticism to condemn Aboriginal law and culture in their entirety, Wilson might have a problem. However, then he would have succumbed to the rub of the "party trick" question.

The chilling effect is most pernicious not when there are things that some people are just itching to say but which would put them in jeopardy under sections 18C and 18D. Discouraging racist and discriminatory behaviour is the very point of these provisions. Rather, the concern about the chilling effect is that regulating speech may discourage people from publicly engaging in controversial issues even when what they have to say may be valuable and perfectly legitimate as far as the law is concerned. The concern, in other words, is that a climate of political correctness is created in which people "walk on egg shells" or, worse, simply disengage.

Three points are worth making about this concern. First, the psychology and sociology behind such "chilling" effects are well documented. People do routinely anticipate and assess the likely consequences in managing their choices and conduct. In political science, the theory of anticipated reactions identifies a 
key dimension of power (Bachrach \& Baratz 1970; Lukes 1974). For example, presidents and prime ministers sometimes decline to bring a legislative bill to a vote if they think they lack the numbers to have it passed. Employees will often not vent a grievance at a meeting with the boss if they fear a tirade or retribution. Joe and Josephine Citizen might not publicly engage on contentious issues if they anticipate a public brawl or legal ramifications. These effects are elementary, mundane, and real.

Second, the idea that sections 18C and 18D of the RDA have created in Australia just such a generalised and pernicious chilling effect seems fanciful. On this argument, Australian public discourse has been artificially impoverished through self-censorship and been less than robust since 1995. Such propositions fly in the face of evidence. For example, when Howard came to power in 1996, there was much talk by him and his government of how for too long Australians had been living under the scourge of political correctness, unable or unwilling to speak their mind for fear of offending minorities. Although Part 2A was added to the RDA in the year prior to Howard's coming to power, the next half decade saw the xenophobic phenomena of Pauline Hanson and Hansonism. ${ }^{3}$ Nothing in the RDA prevented people from speaking their minds, often in ugly ways. Nothing in the RDA prevented Hanson from being elected to the Senate in 2016 and from continuing to rail against particular minorities.

Third, those who believe that section $18 \mathrm{C}$ does have a generalised and pernicious chilling effect need a better cause célèbre than the Andrew Bolt case. As one of the most read columnists in the country and a man who, in the aftermath of his legal entanglement with the RDA, was handed his own public affairs television program, Bolt is hardly a compelling example of the way section $18 \mathrm{C}$ silences people. The general public seemed instinctively to appreciate this in overwhelmingly withholding their support of the government's reforms.

Any semblance of symmetry between ordinary folk being intimidated by section $18 \mathrm{C}$ from speaking their minds and minorities being intimidated by hate speech is not borne out by the circumstances. Importantly, this does not mean that the current racial hatred provisions should be the last word on the matter. Soon after the racial hatred provisions were added to the RDA in 1995, then Race Discrimination Commissioner Zita Antonios oversaw a review of the legislation. It asked probing questions about whether the right balance between protection from discrimination and free speech had been struck (Race Discrimination Commissioner 1995, 1996). Such a review should be ongoing. For example, a case can be made that the words "offend" and "insult" in the section $18 \mathrm{C}$ provisions are, semantically, too sensitive. In the RDA, they operate together with other criteria in the context of discrimination to form a "high bar" for legislative purview. No one merely insulted or taking offense can seek relief under the Act. Nevertheless, these terms lend themselves to public misunderstanding, frivolous and opportunistic complaints and polemical mischief.

The 2016 national election saw Prime Minister Malcolm Turnbull (who had earlier replaced Abbott in a Liberal Party leadership spill) and the Liberal-National Coalition retain majority government by a single seat. Soon after, a group of conservative and libertarian parliamentarians sought to put reform of section $18 \mathrm{C}$ back on the agenda. This time the quest was to have the words "offend" and "insult" removed from the anti-vilification provisions (Lewis 2016). Turnbull initially refused to revisit the issue given his predecessor's debacle. After further agitation by some conservative colleagues, he agreed to a parliamentary inquiry into freedom of speech in Australia. ${ }^{4}$ The inquiry did not ultimately recommend major changes to the race hate laws (Hunter 2017). Turnbull nevertheless acceded to calls within his party to replace the words "offend, insult, humiliate" in $18 \mathrm{C}$ with "harass", while retaining "intimidate". The government proposed once again that a "reasonable member of the Australian community" standard be applied to establishing contraventions of $18 \mathrm{C}$ instead of a member of the targeted community, as currently

3 Pauline Hanson is a populist, rightwing politician who was first elected to the parliament as an independent candidate in 1996. The following year, she founded Pauline Hanson's One Nation, whose party platform was anti-immigration, anti-multiculturalism, anti-Asians, anti-“handouts” to Aborigines, and Australia for white Anglo-Celtic Australians. After some initial electoral success in the late 1990s, her and her party's fortunes withered. She was elected to the Australian Senate in 2016 after almost two decades of unsuccessfully seeking re-election. Her main target today is Muslims and Islam.

4 Parliamentary Joint Committee on Human Rights Inquiry, 2016: freedom of speech in Australia. 
applies (Grattan 2017). In an extraordinary move, the government announced these proposed changes on Harmony Day, a longstanding multicultural initiative to combat racism and to promote social cohesion. Held on 21 March, the day coincides with the United Nations International Day for the Elimination of Racial Discrimination. Community leaders were critical of the changes and scathing about the timing (Malone 2017). In the end, the proposed reforms were rejected in the Senate.

The irony and shame of this protracted free speech episode is that had the Abbott government sought a modest reform of the words "offend" and "insult" in the first place, in proper consultation with ethnic minorities, it might well have won the day. Instead of riding roughshod over minorities' concerns, a genuine attempt at ICD could have bequeathed sensible improvements to the current racial hatred provisions. All Australians are arguably the poorer for this missed opportunity in ICD.

\section{Conclusion}

The proposition that multiculturalism stands in the way of meaningful ICD is increasingly advanced in international scholarly and policy discourse. The Australian experience does not support this proposition. The main obstacle to ICD in Australia has been a powerful current of Anglo-Australian indifference, if not condescension, towards cultural minorities and their place in the Australian society. Australian multiculturalism was meant to check Anglo-Australian dominance but remains challenged by it.

All Australian governments too often ignore the concerns of cultural minorities in formulating policy that directly bears on them. In this, they flout the spirit and the terms of Australian multiculturalism. Minorities also have a responsibility to respect these terms. The two case studies considered in this paper - the federal government's flagging of a proposed citizenship test and its attempt to reform the RDA suggest that far from undermining ICD, respecting the terms of Australian multiculturalism would help to make it possible. Moreover, these cases suggest that if implemented, ICD could contribute improved policy outcomes for all Australians. ICD is not only possible under a multiculturalism regime. It is also made possible by a multiculturalism regime such as Australia and, indeed, is required by such a regime if the latter is to be successful.

\section{References}

ACPEA-see Australian Council on Population and Ethnic Affairs.

Anderson, S. 2015. 'More applicants failing Australia's citizenship test following increase of passing mark', $A B C$ News, 11 November.

Aston, H. 2014a. 'Few back change to race laws', The Sydney Morning Herald, 1 August. 2014b. 'Tony Abbott dumps controversial changes to 18C racial discrimination laws', The Sydney Morning Herald, 5 August.

Australian Council on Population and Ethnic Affairs. 1982. Multiculturalism for all Australians: our developing nationhood, Canberra: Australian Government Publishing Service.

Australian Jewish News. 2008. 'Jews silenced at Canberra talkfest', 6 March.

Bachrach, P \& Baratz, MS. 1970. Power and poverty: theory and practice, New York: Oxford University Press.

Bader, V. 2007. Secularism or democracy? associational governance of religious diversity, Amsterdam: Amsterdam University Press.

Barrett, M (ed.). 2013. Interculturalism and multiculturalism: similarities and differences, Strasbourg: Council of Europe. Brandis, G. 2014. Exposure draft: freedom of speech (repeal of S.18C) Bill 2014, Canberra: Attorney-General's Department. Betts, K. 2002. 'Democracy and dual citizenship', People and Place, vol. 10, no. 1, pp. 57-70.

Betts, K \& Birrell, B. 2007. 'Making Australian citizenship mean more’, People and Place, vol. 15, no. 1, pp. 45-61.

Bouchard, G. 2011. 'What is interculturalism?’, McGill Law Journal, vol. 56, no. 2 pp. 435-468.

Butterly, N. 2008. 'Migrants flunk citizenship test', The Age, 2 January.

Cantle, T. 2012. Interculturalism: the new era of cohesion and diversity, Basingstoke: Palgrave Macmillan.

Carens, J. 2000. Culture, citizenship, and community: a contextual exploration of justice as evenhandedness. Oxford: Oxford University Press. 
Commonwealth of Australia. 1999. A new agenda for multicultural Australia, Canberra: Australian Government Publishing Service. 2003. Multicultural Australia: united in diversity, Canberra: Australian Government Publishing Service. 2006. 'Australian citizenship: much more than a ceremony', Consideration of the merits of introducing a formal citizenship test, Discussion Paper, Canberra: Australian Government Publishing Service.

Council of Europe. 2008. 'Intercultural dialogue: living together as equals in dignity', White Paper, Committee of Ministers, Strasbourg: Council of Europe.

Department of Immigration and Citizenship. 2011. The people of Australia: Australia's multicultural policy, Canberra: Australian Government Publishing Service.

Department of Immigration and Multicultural Affairs. 2002. Muslim Community Reference Group, advisory group, 18 September, Canberra: Australian Government Publishing Service..

Department of Social Services. 2017. Multicultural Australia: united, strong, successful, Canberra: Australian Government Publishing Service.

DIAC-see Department of Immigration and Citizenship.

DIMA-see Department of Immigration and Multicultural Affairs.

DSS-see Department of Social Services.

Eatock v Bolt [2011] FCA 1103 (28 September 2011).

ECCV-see Ethnic Communities Council of Victoria.

Ethnic Communities Council of Victoria. 2006a. 'Australian citizenship: much more than a ceremony' ECCV Submission to the Discussion Paper, 15 November. 2006b. 'ECCV Rejects Robb’s Comments', Media Release, 27 November.

Fraser, N. 2002. 'Recognition without ethics', in S Lash \& M Featherstone (eds), Recognition and difference: politics, identity, multiculture, London: Sage Publications, pp. 21-42.

Grattan, M. 2017. 'Section $18 \mathrm{C}$ change appears doomed in Senate', The Conversation, 21 March.

Hartwich, OM. 2011. Selection, migration and integration: why multiculturalism works in Australia (and fails in Europe), St Leonards: Centre for Independent Studies.

Hunter, F. 2017. 'Free speech inquiry stops short of recommending major changes to $18 \mathrm{C}$ race hate laws', The Sydney Morning Herald, 28 February.

Kelly, P. 1997. 'The curse of the m-word', The Weekend Australian, 30-31 August.

Kuhn, R. 2009. 'Xenophobic racism and class during the Howard years', Marxist Interventions, no. 1, pp. 53-82.

Kymlicka, W. 2012. 'Comment on Meer and Modood', Journal of Intercultural Studies, vol. 33, pp. 211-16.

Levey, GB. 2008. 'Multiculturalism and Australian national identity'. In Political theory and Australian multiculturalism, ed. Geoffrey Brahm Levey, pp. 254-76. New York: Berghahn Books.

2012. 'Interculturalism vs. multiculturalism: a distinction without a difference?', Journal of Intercultural Studies, vol. 33, pp. 217-24.

2014. 'Liberal nationalism and the Australian citizenship tests', Citizenship Studies, vol. 18, pp. 175-89.

2016. 'Diversity, duality and time', in N Meer, T Modood \& R Zapata-Barrero, Multiculturalism and interculturalism: debating the dividing lines, Edinburgh: Edinburgh University Press.

Lewis, R. 2016. 'Support grows for Cory Bernardi's change to section 18C', The Australian, 30 August.

Lukes, S. 1974. Power: a radical view, New York: Macmillan.

Malone, U. 2017. 'Section 18C: ethnic groups believe racial discrimination law changes send wrong message', ABC News, 21 March.

Meer, N \& Modood, T. 2012. 'How does interculturalism contrast with multiculturalism?', Journal of Intercultural Studies, vol. 33, no. 2, pp. 175-196.

Meer, N, Modood, T \& Zappata-Barrero, R (eds.). 2016. Multiculturalism and interculturalism: debating the dividing lines, Edinburgh: Edinburgh University Press.

Office of Multicultural Affairs. 1989. National agenda for a multicultural Australia, Canberra: Australian Government Publishing Service.

OMA-see Office of Multicultural Affairs.

Parekh, B. 1996. 'Minority practices and principles of toleration', International Migration Review, vol. 30, pp. $251-84$. 2000. Rethinking multiculturalism. London: Macmillan.

Race Discrimination Commissioner. 1995. The racial discrimination act: a review, Canberra: Australian Government Publishing Service. 1996. The racial discrimination act: a review. community consultation guide, Canberra: Australian Government Publishing Service.

Robb, A. 2006a. 'The importance of a shared national identity', Plenary address to the transformations conference, Canberra: Australian National University, 27 November.

2006b. 'In support of a formal citizenship test', Address to the Jewish National Fund, Melbourne: Mercantile Rowing Club, 25 October.

Shaw, M. 2004. 'Howard puts ATSIC to death', The Age, 16 April. 
Soutphommasane, T. 2014. 'Tim Soutphommasane and Tim Wilson debate racial discrimination backflip', ABC Radio National Breakfast, 6 August.

Tate, J. 2009. 'John Howard's “Nation” and citizenship test: multiculturalism, citizenship, and identity', Australian Journal of Politics and History, vol. 55, no. 1, pp. 97-120.

Taylor, C. 2012. 'Interculturalism or multiculturalism?’, Philosophy \& Social Criticism, vol. 38, pp. 413-23.

van Vliet, P. 2006. 'Diversity is a fact, not a doctrine', The Age, 29 November.

Whitlam, Hon. EG. 1975. Launch of the office of the commissioner for community relations, Canberra.

Wieviorka, M. 2012. 'Multiculturalism: a concept to be redefined and certainly not replaced by the extremely vague term of interculturalism', Journal of Intercultural Studies, vol. 33, pp. 225-31.

Wilson, T. 2015. 'Charlie Hebdo vs 18C: no contest', The Australian, 19 January.

Wright, J. 2013. 'George Brandis to repeal “Bolt laws” on racial discrimination', The Sydney Morning Herald, 8 November. Young, IM. 1990. Justice and the politics of difference, Princeton: Princeton University Press.

Zapata-Barrero, R (ed.). 2015b. Interculturalism in cities: concept, policy and implementation, Cheltenham: Edward Elgar.

\section{Legislation}

Racial Discrimination Act 1975 (Cth) 